\title{
First-milking colostrum mineral concentrations and yields: Comparison to second milking and associations with serum mineral concentrations, parity, and yield in multiparous Jersey cows
}

\author{
A. Valldecabres ${ }^{1,2 *} \dagger \odot$ and N. Silva-del-Río ${ }^{1,2} \odot$ \\ ${ }^{1}$ Veterinary Medicine Teaching and Research Center, University of California, Davis, 18830 Road 112, Tulare 93274 \\ ${ }^{2}$ Department of Population Health and Reproduction, School of Veterinary Medicine, University of California, Davis 95616
}

\begin{abstract}
This observational study described first-milking colostrum mineral concentrations and total yields, and evaluated its associations with cow serum mineral concentrations, parity, and first postpartum milking yield in 100 multiparous Jersey cows from a single herd fed a negative dietary cation-anion difference diet prepartum. Additionally, first- and second-milking colostrum mineral concentrations and total yields were compared in a subset of 65 cows. Serum minerals $(\mathrm{Ca}, \mathrm{P}, \mathrm{Mg}, \mathrm{Na}$, $\mathrm{K}, \mathrm{Zn}, \mathrm{Fe}, \mathrm{Cu}$ ) were assessed before first milking. Cows were milked at $9 \mathrm{~h}$ and $4 \mathrm{~min} \pm 3 \mathrm{~h}$ and $32 \mathrm{~min}$ and at $21 \mathrm{~h}$ and $11 \mathrm{~min} \pm 3 \mathrm{~h}$ and 43 min postpartum ( \pm standard deviation); yields were recorded and samples collected for mineral concentrations assessment (Ca, P, $\mathrm{Mg}, \mathrm{Na}, \mathrm{K}, \mathrm{Zn}, \mathrm{Fe}, \mathrm{Cu})$. Linear regression was used to evaluate the associations between first-milking colostrum mineral concentrations and total yields and cows' serum mineral concentrations, parity, first-milking colostrum yield, and calving-to-milking interval. The most abundant minerals in first-milking colostrum were (least squares mean \pm standard error of the mean) Ca $(55.71 \pm 13.52 \mathrm{mmol} / \mathrm{L} ; 8.75 \pm 5.74 \mathrm{~g})$ and $\mathrm{P}(41.91 \pm$ $13.01 \mathrm{mmol} / \mathrm{L} ; 5.26 \pm 3.72 \mathrm{~g})$, followed by $\mathrm{Na}(39.65 \pm$ $13.23 \mathrm{mmol} / \mathrm{L} ; 3.08 \pm 1.77 \mathrm{~g}), \mathrm{K}(36.47 \pm 7.57 \mathrm{mmol} / \mathrm{L}$; $5.79 \pm 4.20 \mathrm{~g}), \mathrm{Mg}(13.43 \pm 3.09 \mathrm{mmol} / \mathrm{L} ; 1.25 \pm 0.78$ g), Zn (272.12 $\pm 113.34 \mu \mathrm{mol} / \mathrm{L} ; 71.98 \pm 55.34 \mathrm{mg}), \mathrm{Fe}$ $(12.51 \pm 3.79 \mu \mathrm{mol} / \mathrm{L} ; 2.56 \pm 1.55 \mathrm{mg})$, and $\mathrm{Cu}(3.34$ $\pm 1.22 \mu \mathrm{mol} / \mathrm{L} ; 0.77 \pm 0.56 \mathrm{mg})$. Higher concentrations of $\mathrm{Ca}, \mathrm{Mg}, \mathrm{Na}, \mathrm{Zn}, \mathrm{Fe}$, and $\mathrm{Cu}$, and total yields of $\mathrm{Mg}$, $\mathrm{Zn}, \mathrm{Fe}$, and $\mathrm{Cu}$ were observed at first- compared with second-milking colostrum. Serum and first-milking colostrum $\mathrm{Cu}$ concentrations were positively associated, but no significant associations were observed between
\end{abstract}

Received July 27, 2021.

Accepted November 13, 2021.

* Current address: Teagasc, Animal and Grassland Research and Innovation Center, Moorepark, Fermoy, Co. Cork, Ireland P61 C996.

†Corresponding author: ainhoa.valldecabres@teagasc.ie other minerals' serum and first-milking colostrum concentrations or total yields. Parity was associated with first-milking colostrum $\mathrm{Ca}, \mathrm{P}, \mathrm{K}$, and Fe concentrations and yields; younger multiparous cows had higher concentrations and total yields of these minerals. Linear $(\mathrm{Fe})$, quadratic $(\mathrm{P}, \mathrm{Na}$, and $\mathrm{K})$, and cubic $(\mathrm{Mg}, \mathrm{Zn}$, and $\mathrm{Cu}$ ) associations were observed between first-milking colostrum mineral concentrations and yield. In all cases, mineral total yields were linearly associated with first-milking colostrum yield. In conclusion, variation in first-milking colostrum mineral concentrations and total yields across cows could be partially explained by cow parity and colostrum yield. Further research including primiparous and cows under different management settings is needed to expand the knowledge and understanding of colostrum mineral concentrations and total yields in dairy cows.

Key words: colostrum, trace mineral, dairy cow, Jersey

\section{INTRODUCTION}

Colostrum, in addition to a source of passive immunity, is an important source of nutrients such as carbohydrates, fats, proteins, minerals, vitamins, and bioactive components (Kehoe et al., 2007; Morrill et al., 2012; Playford and Weiser, 2021). Although the literature available is limited, all studies seem to suggest that mineral concentrations of first-milking colostrum are higher than those at subsequent milkings, suggesting their importance for the neonate calf (Foley and Otterby, 1978; Kume and Tanabe, 1993; Tsioulpas et al., 2007). It is well established that milk composition varies across breeds (Cerbulis and Farrell, 1976; Auldist et al., 2004; Carroll et al., 2006), but little is known about the colostrum mineral concentrations and total yields in breeds other than Holstein. There is growing evidence of the involvement of minerals on immune and antioxidant responses key to preserve calf health, and there is interest on trace mineral supplementation to maximize these positive effects in calves (Teixeira et 
al., 2014; Kertz et al., 2017; Bates et al., 2019). Thus, although mineral requirements of neonate calves are not clearly defined, further description and understanding of factors influencing colostrum mineral concentrations are warranted to allow for an optimum use of this supply. Furthermore, total yields of minerals in colostrum might be associated with cow postpartum mineral imbalance (Goff et al., 2002; Vanacker et al., 2017; Valldecabres et al., 2021), bringing interest to the illustration and study of mineral losses in dairy cows early postpartum.

Several factors such as breed, parity, calf sex, twinning, month of calving, dry period length, previous lactation length, and health have been associated with colostrum yield (Parrish et al., 1950; Maunsell et al., 1998; Gavin et al., 2018). Similarly, colostrum immunoglobulin concentration varies based on time from calving, parity, dry period length, dry period nutrition, productive potential, and yield (Kehoe et al., 2011; Mann et al., 2016; Dunn et al., 2017). However, there is limited research evaluating factors that may affect other colostrum nutrients. The association of colostrum mineral concentrations with parity has been studied (Kume and Tanabe, 1993; Kume et al., 1998), but more research is needed, particularly with breeds other than Holstein.

Based on previous evidence, we expected that first-milking colostrum mineral concentrations and total yields would be associated with serum mineral concentrations, parity, and colostrum yield in multiparous Jersey cows, and that a higher concentration of minerals would be observed in first- compared with second-milking colostrum. Thus, the objectives of the present study were to characterize first-milking colostrum mineral concentrations and total yields, and to evaluate its associations with cow serum mineral concentrations, parity, and first-milking colostrum yield in 100 multiparous Jersey cows from a single herd fed a negative DCAD diet prepartum. Additionally, firstand second-milking colostrum mineral concentrations and total yields were compared in a subset of 65 cows. The information presented herein aims to contribute to the knowledge on colostrum mineral composition, and to provide additional understanding of factors influencing its mineral concentrations and total yields in multiparous Jersey cows under the specific conditions described above.

\section{MATERIALS AND METHODS}

All procedures were approved by the University of California Davis Institutional Animal Care and Use Committee (\#18846).

\section{Study Herd Management}

The study was conducted on a commercial dry-lot Jersey herd in California from January to February 2016. The herd milked 2,789 cows twice a day in a double herringbone parlor and averaged $23.8 \mathrm{~kg} / \mathrm{d}$ of milk (with $5.1 \%$ fat and $3.9 \%$ protein) per cow during the study period.

During the last 3 wk before expected calving, dry cows were moved to a close-up pen and offered a corn silage-based TMR with anionic salts once a day (DCAD: $-17.61 \mathrm{mEq} / 100 \mathrm{~g}$ of DM). Close-up cows showing early signs of calving (udder development, vulva, and pelvic ligaments relaxation) were moved to a prepartum pen. Once cows showed signs of first stage of calving, they were moved into individual calving pens bedded with straw. Calves were separated from dams immediately after parturition. Study herd periparturient cow management did not involve postpartum mineral supplementation. Twice a day, fresh cows were moved from the maternity pen to a colostrum pen, where they stayed for $4 \mathrm{~d}$ before they were moved into fresh cow and lactation pens. All postpartum cows were offered a winter forage silage-based TMR twice a day. Mineral concentrations of the close-up and fresh cow diet were as follows (\% of DM): $\mathrm{Ca}, 2.86$ and 1.19; $\mathrm{P}$, 0.40 and $0.48 ; \mathrm{Mg}, 0.43$ and $0.36 ; \mathrm{Na}, 0.13$ and $0.29 ; \mathrm{K}$, 1.27 and $1.37 ; \mathrm{Cl}, 0.92$ and 0.43 ; and $\mathrm{S}, 0.47$ and 0.34 ; and $(\mathrm{mg} / \mathrm{kg}): \mathrm{Zn}, 71$ and $69 ; \mathrm{Fe}, 637$ and 547; and $\mathrm{Cu}$, 23 and 15, respectively. Detailed ingredient and additional nutrient description of the diets can be found in Valldecabres et al. (2018).

\section{Experimental Design and Data Collection}

A convenience sample of 100 multiparous Jersey cows calving between January and February of 2016 as part of a study evaluating first- and second-milking colostrum IgG concentrations (Silva-del-Río et al., 2017) had colostrum mineral concentrations determined and was used in the present observational study. All cows calving within the study period were enrolled and followed up to first $(\mathrm{n}=100)$ and second postpartum milking $(\mathrm{n}=65)$. Follow up after the first milking was decided after enrollment initiation; therefore, cows enrolled during the initial phase of the study were not followed up to the second milking. Farm personnel milked cows using individual milking buckets at $9 \mathrm{~h}$ and $4 \mathrm{~min} \pm 3$ $\mathrm{h}$ and 32 min (first-milking colostrum harvesting; mean $\pm \mathrm{SD}$ ) and at $21 \mathrm{~h}$ and $11 \mathrm{~min} \pm 3 \mathrm{~h}$ and $43 \mathrm{~min}$ after calving (second-milking colostrum harvesting; mean $\pm \mathrm{SD}$ ) according to standard practices at the dairy. After each cow was milked, researchers transferred 
harvested colostrum into plastic containers that were weighed using a portable scale with a readability of 0 to $50 \mathrm{~kg} \pm 2 \mathrm{~g}$ (Ship-Elite, American Weight Scales Inc.). Colostrum samples were then collected directly from the plastic buckets after manual homogenization into $20-\mathrm{mL}$ plastic vials and transported to the laboratory. Upon arrival, 2 subsamples of $5 \mathrm{~mL}$ were stored at $-20^{\circ} \mathrm{C}$ until the end of the field trial. At study completion, a set of frozen samples was shipped to the California Animal Health and Food Safety Laboratory (University of California, Davis) for macro- and traceminerals determination by Inductively Coupled Plasma - Optical Emission Spectrometry (ICP-OES; Melton et al., 1990). Before ICP-OES, colostrum was mixed with a protein-precipitating internal standard solution, containing trichloroacetic acid, hydroxylamine sulfate, hydrochloric acid, and yttrium. The sample was then centrifuged at $1,100 \times g$ for 3 min at room temperature, and the clear supernatant was analyzed by ICP-OES. The intra-assay and interassay coefficients of variation for colostrum minerals were 10.1 and $6.3 \%$ for $\mathrm{Ca}, 5.9$ and $5.6 \%$ for $\mathrm{P}, 3.9$ and $4.2 \%$ for $\mathrm{Mg}, 3.1$ and $2.1 \%$ for $\mathrm{Na}, 2.7$ and $1.6 \%$ for K, 16.3 and $13.5 \%$ for $\mathrm{Zn}, 6.6$ and $10.0 \%$ for $\mathrm{Fe}$, and 11.4 and $8.4 \%$ for $\mathrm{Cu}$, respectively.

Blood samples for serum Ca, P, Mg, Na, K, Zn, Fe, and $\mathrm{Cu}$ determination were collected from the coccygeal vessels using an evacuated tube without anticoagulant (BD Vacutainer, Trace Element Serum; BD) before first postpartum milking at $2 \mathrm{~h}$ and $46 \mathrm{~min} \pm 2 \mathrm{~h}$ and 15 min postpartum (mean $\pm \mathrm{SD}$ ). Immediately after drawing blood, samples were placed into a portable refrigerator set at $4^{\circ} \mathrm{C}$ and transported to the laboratory within $3 \mathrm{~h}$ after collection. Samples were centrifuged at $1,430 \times g$ for $15 \mathrm{~min}$, and serum was stored at $-20^{\circ} \mathrm{C}$ until analysis. Frozen serum samples were shipped to the California Animal Health and Food Safety Laboratory (University of California, Davis) for macro- and trace-minerals determination as described above. The intra-assay and interassay coefficients of variation have been described in Valldecabres et al. (2018).

At the time of blood sample collection, cows were scored for body condition and locomotion using a 1-to5 scale with 0.25 - and 1-unit increments, respectively (Ferguson et al., 1994; Sprecher et al., 1997). Time of calving was transferred from the farm worksheets to the study database, and parity information was obtained from the herd management software at study completion (DairyComp305 records; Valley Agricultural Software).

\section{Statistical Analyses}

All statistical analyses were performed in SAS version 9.4 (SAS Institute Inc.). Colostrum mineral total yields were calculated as mineral concentration $(\mathrm{mg} /$ $\mathrm{kg}) \times$ colostrum yield $(\mathrm{kg})$, and transformed to the appropriate SI unit. Mineral concentrations and total yields in first-milking colostrum were described for the 100 multiparous cows included in the study using the MEANS procedure. First- and second-milking colostrum mineral concentrations and total yields were compared with linear regression using the MIXED procedure for the subset of 65 cows with mineral concentrations and total yields determined in first- and second-milking colostrum. Models included the effect of postpartum milking number and cow as the subject of the repeated measures statement with compound symmetry variance-covariance structure. The LSMEANS statement with the CL option was used to obtain the least squares means for mineral concentrations and total yields and the respective $95 \%$ confidence intervals.

The associations between first-milking colostrum mineral concentrations or total yields and cow serum mineral concentrations, parity $(2,3,4$, and $\geq 5)$, firstmilking colostrum yield, and calving-to-first milking interval were evaluated through multiple linear regression using the MIXED procedure in separate models for each mineral. Continuous predictor variables were screened for outliers using the UNIVARIATE procedure; 2 observations were considered outliers (likely the result of measurement errors) and not included in the analyses $[3.24 \mathrm{mmol} / \mathrm{L}$ serum $\mathrm{Ca}(+4.4 \mathrm{SD}$ from the mean); $1.65 \mathrm{mmol} / \mathrm{L}$ serum $\mathrm{Mg}(+4.1 \mathrm{SD}$ from the mean)]. Before beginning the model building process, multicollinearity among independent explanatory variables was evaluated with the VIF tool of the REG procedure; collinearity was not detected. The assumption of linear relationship between dependent and independent continuous variables was graphically assessed with the LOESS option from the SGPLOT procedure, and power terms of serum mineral concentrations and first-milking colostrum yield were added to the models as needed. All explanatory variables were offered to the models simultaneously. Cow serum mineral concentrations, parity, and first-milking colostrum yield were retained in the final models regardless of the $P$-value as variables of interest. The effect of calving-to-first milking interval (in minutes) was removed from the multivariable models at $P>0.10$. Power terms of serum mineral concentrations and first-milking colostrum yield were only removed from the models if unnecessary to meet the continuous predictor-outcome linear association assumption, which was reassessed by plotting the final model residuals against each of the continuous predictors as described above. The LSMEANS statement with Bonferroni adjustment was used to quantify and evaluate the association between first-milking colostrum mineral concentrations or total yields and 
Table 1. Mineral concentrations and yields of colostrum harvested at first postpartum milking $(9 \mathrm{~h}$ and 4 min $\pm 3 \mathrm{~h}$ and $32 \mathrm{~min}$ postpartum) from 100 multiparous Jersey from a commercial farm in California

\begin{tabular}{|c|c|c|c|c|c|}
\hline \multirow[b]{2}{*}{ Mineral } & \multirow[b]{2}{*}{$\mathrm{n}$} & \multicolumn{2}{|c|}{ Concentration $(\mathrm{mmol} / \mathrm{L} \text { or } \mu \mathrm{mol} / \mathrm{L})^{1}$} & \multicolumn{2}{|c|}{ Total yield $(\mathrm{g} \text { or } \mathrm{mg})^{2}$} \\
\hline & & Mean & $95 \%$ CI & Mean & $95 \%$ CI \\
\hline $\mathrm{Ca}$ & 99 & 55.72 & $53.02-58.41$ & 8.75 & $7.60-9.89$ \\
\hline $\mathrm{P}$ & 99 & 41.91 & $39.31-44.50$ & 5.26 & $4.52-6.00$ \\
\hline $\mathrm{Mg}$ & 99 & 13.44 & $12.83-14.06$ & 1.25 & $1.09-1.40$ \\
\hline $\mathrm{Na}$ & 99 & 37.83 & $35.20-40.47$ & 3.08 & $2.73-3.44$ \\
\hline $\mathrm{K}$ & 99 & 36.31 & $34.80-37.82$ & 5.79 & $4.96-6.63$ \\
\hline $\mathrm{Zn}$ & 98 & 272.13 & $249.41-294.85$ & 71.98 & $60.89-83.08$ \\
\hline $\mathrm{Fe}$ & 99 & 12.51 & $11.76-13.27$ & 2.56 & $2.25-2.87$ \\
\hline $\mathrm{Cu}$ & 92 & 3.34 & $3.09-3.59$ & 0.77 & $0.66-0.89$ \\
\hline
\end{tabular}

${ }^{1}$ Concentration is presented in mmol/L $(\mathrm{Ca}, \mathrm{Mg}, \mathrm{P}, \mathrm{Na}, \mathrm{K})$ or $\mu \mathrm{mol} / \mathrm{L}(\mathrm{Zn}, \mathrm{Fe}, \mathrm{Cu})$.

${ }^{2}$ Total yield is presented in $\mathrm{g}(\mathrm{Ca}, \mathrm{Mg}, \mathrm{P}, \mathrm{Na}, \mathrm{K})$ or $\mathrm{mg}(\mathrm{Zn}, \mathrm{Fe}, \mathrm{Cu})$.

parity. Homoscedasticity and normality of the final models' residuals were graphically assessed using the plots generated with the residual option from the model statement. The accompanying figure was created with SigmaPlot (version 14.0; Systat Software Inc.). Locally weighted smoothing (loess) with tricube weighting and polynomial regression was used to plot the predicted values from the described models for first-milking colostrum mineral concentrations against first-milking colostrum yield. Significance was declared at $P \leq 0.05$.

\section{RESULTS}

On average, $4.0 \mathrm{~kg}$ of colostrum $(\mathrm{SD}=2.6 \mathrm{~kg} ; \mathrm{n}$ $=100)$ was harvested at first postpartum milking. Colostrum could not be harvested from 1 cow at first postpartum milking; therefore, the final database for first-milking colostrum mineral concentrations and total yields included 99 cows. Additionally, first-milking colostrum $\mathrm{Cu}$ and $\mathrm{Zn}$ concentrations could not be determined from 7 and 1 samples, respectively. Serum mineral concentrations for cows enrolled in the study were on average $( \pm \mathrm{SD})$ as follows (in $\mathrm{mmol} / \mathrm{L}): 1.91$ $\pm 0.29 \mathrm{Ca}, 1.21 \pm 0.42 \mathrm{P}, 1.06 \pm 0.14 \mathrm{Mg}, 140.80 \pm$ $4.44 \mathrm{Na}$, and $4.50 \pm 0.39 \mathrm{~K}$; and (in $\mu \mathrm{mol} / \mathrm{L}$ ): 8.69 $\pm 2.46 \mathrm{Zn}, 20.99 \pm 8.47 \mathrm{Fe}$, and $13.94 \pm 2.78 \mathrm{Cu}$. At blood sample collection, median BCS was 2.75 , and $7 \%$ of cows exhibited lameness, scoring $>2$ for locomotion.

\section{Mineral Concentrations and Total Yields in First-Milking Colostrum}

Mineral concentrations and total yields in first-milking colostrum are summarized in Table 1. As expected $($ mean $\pm \mathrm{SD}), \mathrm{Ca}(55.72 \pm 13.52 \mathrm{mmol} / \mathrm{L} ; 8.75 \pm 5.74$ g) was the most abundant mineral followed in order of decreasing concentration by $\mathrm{P}(41.91 \pm 13.01 \mathrm{mmol} / \mathrm{L}$; $5.26 \pm 3.72 \mathrm{~g}), \mathrm{Na}(37.83 \pm 13.23 \mathrm{mmol} / \mathrm{L} ; 3.08 \pm 1.77$ $\mathrm{g}), \mathrm{K}(36.31 \pm 7.57 \mathrm{mmol} / \mathrm{L} ; 5.79 \pm 4.20 \mathrm{~g}), \mathrm{Mg}(13.44$ $\pm 3.09 \mathrm{mmol} / \mathrm{L} ; 1.25 \pm 0.78 \mathrm{~g}), \mathrm{Zn}(272.13 \pm 113.34$ $\mu \mathrm{mol} / \mathrm{L} ; 71.98 \pm 55.34 \mathrm{mg}), \mathrm{Fe}(12.51 \pm 3.79 \mu \mathrm{mol} / \mathrm{L}$; $2.56 \pm 1.55 \mathrm{mg})$, and $\mathrm{Cu}(3.34 \pm 1.22 \mu \mathrm{mol} / \mathrm{L} ; 0.77 \pm$ $0.56 \mathrm{mg})$.

\section{First- and Second-Milking Colostrum Comparison}

On average, $3.81 \pm 2.42$ and $4.15 \pm 2.09 \mathrm{~kg}$ were harvested at first and second postpartum milking, respectively ( $\pm \mathrm{SD} ; \mathrm{n}=65$ ). Mineral concentrations and total yields in first- and second-milking colostrum are summarized in Table 2. Higher concentrations of $\mathrm{Ca}, \mathrm{Mg}, \mathrm{Na}, \mathrm{Cu}, \mathrm{Fe}$, and $\mathrm{Zn}$ were observed in firstcompared with second-milking colostrum $(P<0.05)$, whereas concentrations of $\mathrm{P}$ and $\mathrm{K}$ were similar in both milkings' colostrum. Total yields of $\mathrm{Mg}, \mathrm{Zn}, \mathrm{Fe}$, and $\mathrm{Cu}$ were also higher in first- compared with second-milking colostrum $(P<0.05)$; however, total yields of Ca, $\mathrm{P}$, $\mathrm{Na}$, and $\mathrm{K}$ were similar in both milkings' colostrum. Overall, the decrease on mineral concentrations from first- to second-milking colostrum was of $12.7 \%$ for Ca, $22.5 \%$ for $\mathrm{Mg}, 9.1 \%$ for $\mathrm{Na}, 34.0 \%$ for $\mathrm{Zn}, 54.6 \%$ for $\mathrm{Fe}$, and $24.7 \%$ for $\mathrm{Cu}$. Additionally, the decrease on mineral yields was of $21.4 \%$ for $\mathrm{Mg}, 34.4 \%$ for $\mathrm{Zn}, 54.2 \%$ for $\mathrm{Fe}$, and $25.0 \%$ for $\mathrm{Cu}$.

\section{Variables Possibly Explaining Mineral Concentrations and Total Yields}

The effect of time from calving to first milking was not significant in any of the models $(P>0.10)$.

Serum Mineral Concentrations. A positive linear association was observed between first-milking colostrum and serum $\mathrm{Cu}$ concentrations; on average, an increase of $1 \mu \mathrm{mol} / \mathrm{L}$ in serum $\mathrm{Cu}$ was associated with an increase of $0.11 \pm 0.05 \mu \mathrm{mol} / \mathrm{L}$ in colostrum $\mathrm{Cu}$ $(P=0.02)$. However, no significant associations were observed between first-milking colostrum and serum mineral concentrations for the other minerals evaluated 
Table 2. Least squares means and 95\% CI for mineral concentrations and yields at first (9 h and 4 min \pm 3 h and 32 min postpartum) and second (21 h and $11 \mathrm{~min} \pm 3 \mathrm{~h}$ and 43 min postpartum) postpartum milking for 65 multiparous Jersey from a commercial farm in California

\begin{tabular}{|c|c|c|c|c|c|c|}
\hline \multirow[b]{2}{*}{ Mineral } & \multicolumn{3}{|c|}{ Concentration $(\mathrm{mmol} / \mathrm{L} \text { or } \mu \mathrm{mol} / \mathrm{L})^{1}$} & \multicolumn{3}{|c|}{ Yield (g or mg) $)^{2}$} \\
\hline & First milking & Second milking & $P$-value & First milking & Second milking & $P$-value \\
\hline $\mathrm{P}$ & $\begin{array}{l}42.80 \\
(39.80-45.79)\end{array}$ & $\begin{array}{l}41.40 \\
(39.51-43.29)\end{array}$ & 0.11 & $\begin{array}{l}5.61 \\
(4.79-6.44)\end{array}$ & $\begin{array}{l}5.41 \\
(4.59-6.24)\end{array}$ & 0.65 \\
\hline $\mathrm{Mg}$ & $\begin{array}{l}13.45 \\
(12.66-14.24)\end{array}$ & $\begin{array}{l}10.43 \\
(9.90-10.97)\end{array}$ & $<0.001$ & $\begin{array}{l}1.31 \\
(1.15-1.48)\end{array}$ & $\begin{array}{l}1.03 \\
(0.87-1.19)\end{array}$ & 0.004 \\
\hline K & $\begin{array}{l}36.49 \\
(34.66-38.33)\end{array}$ & $\begin{array}{l}37.14 \\
(35.85-38.43)\end{array}$ & 0.25 & $\begin{array}{l}6.06 \\
(5.13-6.99)\end{array}$ & $\begin{array}{l}6.17 \\
(5.24-7.1)\end{array}$ & 0.83 \\
\hline $\mathrm{Zn}$ & $\begin{array}{l}297.57 \\
(274.50-320.65)\end{array}$ & $\begin{array}{l}196.60 \\
(173.53-219.68)\end{array}$ & $<0.001$ & $\begin{array}{l}80.81 \\
(69.21-92.4)\end{array}$ & $\begin{array}{l}53.05 \\
(41.45-64.65)\end{array}$ & $<0.001$ \\
\hline $\mathrm{Fe}$ & $\begin{array}{l}12.12 \\
(11.36-12.88)\end{array}$ & $\begin{array}{l}5.42 \\
(4.64-6.20)\end{array}$ & $<0.001$ & $\begin{array}{l}2.64 \\
(2.34-2.94)\end{array}$ & $\begin{array}{l}1.21 \\
(0.9-1.52)\end{array}$ & $<0.001$ \\
\hline
\end{tabular}

${ }^{1}$ Concentration is presented in mmol/L $(\mathrm{Ca}, \mathrm{Mg}, \mathrm{P}, \mathrm{Na}, \mathrm{K})$ or $\mu \mathrm{mol} / \mathrm{L}(\mathrm{Zn}, \mathrm{Fe}, \mathrm{Cu})$.

${ }^{2}$ Total yield is presented in $\mathrm{g}(\mathrm{Ca}, \mathrm{Mg}, \mathrm{P}, \mathrm{Na}, \mathrm{K})$ or $\mathrm{mg}(\mathrm{Zn}, \mathrm{Fe}, \mathrm{Cu})$.

$[P$-value for linear association unless otherwise stated; Ca: $P=0.23, \mathrm{P}: P=0.08, \mathrm{Mg}$ (linear: $P=0.13$; quadratic: $P=0.11$ ), Na: $P=0.07, \mathrm{~K}: P=0.70, \mathrm{Zn}: P=$ 0.41 , and Fe: $P=0.06]$.

No significant associations were observed between mineral total yields in first-milking colostrum and serum mineral concentrations $[P$-value for linear association unless otherwise stated; $\mathrm{Ca}(P=0.23), \mathrm{P}(P=$ $0.11), \mathrm{Mg}(P=0.92), \mathrm{Na}(P=0.48), \mathrm{K}(P=1.00), \mathrm{Zn}$ $(P=0.30)$, Fe (linear: $P=0.11$; quadratic: $P=0.29)$, and $\mathrm{Cu}(P=0.42)]$.

Parity. Parity effects on mineral concentrations in first-milking colostrum are summarized in Table 3 . Parity was associated with colostrum $\mathrm{Ca}(P=0.03)$, $\mathrm{P}(P=0.002), \mathrm{K}(P=0.004)$, and $\mathrm{Fe}(P=0.004)$ concentrations. Compared with greater-than-fifth parity cows, second-parity cows had higher concentrations of $\mathrm{P}(P=0.006), \mathrm{K}(P=0.03)$, and $\mathrm{Fe}(P=0.003)$, and third-parity cows had higher concentrations of $\mathrm{Ca}(P=$ $0.04), \mathrm{P}(P=0.01)$, and $\mathrm{K}(P=0.007)$ in first-milking colostrum. No association was observed between parity and colostrum $\mathrm{Mg}(P=0.19), \mathrm{Na}(P=0.66), \mathrm{Zn}(P=$ $0.98)$, and $\mathrm{Cu}(P=0.17)$ concentrations.

Parity effects on total mineral yields in first-milking colostrum are summarized in Table 4. Parity was associated with total yields of $\mathrm{Ca}(P=0.009), \mathrm{P}(P=$ $0.002)$, $\mathrm{K}(P=0.004)$, and Fe $(P=0.004)$ in firstmilking colostrum. Compared with greater-than-fifth parity cows, second-parity cows had higher total yields of $\mathrm{P}(P=0.006)$, and Fe $(P=0.04)$, and third-parity cows had higher total yields of Ca $(P=0.005), \mathrm{P}(P=$ $0.001)$, and $\mathrm{K}(P=0.007)$ in first-milking colostrum.

Table 3. Least squares means and SEM for the association of parity and mineral concentrations in colostrum harvested at first postpartum milking (9 h and $4 \mathrm{~min} \pm 3 \mathrm{~h} 32 \mathrm{~min}$ postpartum) from 99 multiparous Jersey from a commercial farm in California

\begin{tabular}{|c|c|c|c|c|c|}
\hline \multirow{2}{*}{$\begin{array}{l}\text { Mineral } \\
(\mathrm{mmol} / \mathrm{L} \text { or } \mu \mathrm{mol} / \mathrm{L})^{1}\end{array}$} & \multicolumn{4}{|c|}{ Parity } & \multirow[b]{2}{*}{$P$-value 2} \\
\hline & $2(\mathrm{n}=27)$ & $3(\mathrm{n}=26)$ & $4(\mathrm{n}=11)$ & $\geq 5(\mathrm{n}=35)$ & \\
\hline $\mathrm{P}$ & $45.97 \pm 2.25^{\mathrm{a}}$ & $45.31 \pm 2.25^{\mathrm{a}}$ & $43.13 \pm 3.41^{\mathrm{ab}}$ & $35.85 \pm 1.91^{\mathrm{b}}$ & 0.002 \\
\hline $\mathrm{Mg}$ & $13.57 \pm 0.64$ & $14.30 \pm 0.62$ & $13.90 \pm 0.96$ & $12.54 \pm 0.54$ & 0.19 \\
\hline $\mathrm{Na}$ & $40.14 \pm 2.42$ & $37.55 \pm 2.44$ & $34.97 \pm 3.68$ & $37.17 \pm 2.08$ & 0.66 \\
\hline $\mathrm{K}$ & $37.90 \pm 1.21^{\mathrm{a}}$ & $38.61 \pm 1.22^{\mathrm{a}}$ & $36.87 \pm 1.86^{\mathrm{ab}}$ & $33.21 \pm 1.04^{\mathrm{b}}$ & 0.004 \\
\hline $\mathrm{Cu}$ & $3.25 \pm 0.24$ & $3.84 \pm 0.26$ & $3.09 \pm 0.39$ & $3.14 \pm 0.21$ & 0.17 \\
\hline
\end{tabular}

${ }^{\mathrm{a}, \mathrm{b}}$ Least squares means within a row with different superscripts differ $(P<0.05)$.

${ }^{1}$ Concentration is presented in $\mathrm{mmol} / \mathrm{L}(\mathrm{Ca}, \mathrm{Mg}, \mathrm{P}, \mathrm{Na}, \mathrm{K})$ or $\mu \mathrm{mol} / \mathrm{L}(\mathrm{Zn}, \mathrm{Fe}, \mathrm{Cu})$.

${ }^{2}$ Models also included the effects of serum mineral concentration (linear, quadratic, or cubic as appropriate), and yield at first postpartum milking (linear, quadratic, or cubic as appropriate). 
Table 4. Least squares means and SEM for the association of parity and total mineral yields in colostrum harvested at first postpartum milking (9 h and $4 \mathrm{~min} \pm 3 \mathrm{~h} 32$ min postpartum) from 99 multiparous Jersey from a commercial farm in California

\begin{tabular}{lccccc}
\hline & \multicolumn{4}{c}{ Parity } & \\
\cline { 2 - 4 } $\begin{array}{l}\text { Mineral } \\
\text { (g or mg })^{1}\end{array}$ & $2(\mathrm{n}=27)$ & $3(\mathrm{n}=26)$ & $4(\mathrm{n}=11)$ & $\geq 5(\mathrm{n}=35)$ & $P$-value $^{2}$ \\
\hline $\mathrm{Ca}$ & $8.81 \pm 0.42^{\mathrm{ab}}$ & $9.72 \pm 0.39^{\mathrm{a}}$ & $8.96 \pm 0.59^{\mathrm{ab}}$ & $7.77 \pm 0.37^{\mathrm{b}}$ & 0.009 \\
$\mathrm{P}$ & $5.48 \pm 0.26^{\mathrm{ab}}$ & $5.92 \pm 0.26^{\mathrm{a}}$ & $5.35 \pm 0.40^{\mathrm{b}}$ & $4.58 \pm 0.22^{\mathrm{b}}$ & 0.002 \\
$\mathrm{Mg}$ & $1.23 \pm 0.06$ & $1.32 \pm 0.06$ & $1.26 \pm 0.10$ & $1.19 \pm 0.05$ & 0.45 \\
$\mathrm{Na}$ & $3.10 \pm 0.18$ & $3.12 \pm 0.19$ & $2.85 \pm 0.28$ & $3.12 \pm 0.16$ & 0.85 \\
$\mathrm{~K}$ & $5.99 \pm 0.21^{\mathrm{ab}}$ & $6.21 \pm 0.22^{\mathrm{a}}$ & $6.08 \pm 0.33^{\mathrm{ab}}$ & $5.24 \pm 0.19^{\mathrm{b}}$ & 0.004 \\
$\mathrm{Zn}$ & $71.34 \pm 6.45$ & $76.93 \pm 6.71$ & $69.07 \pm 9.80$ & $69.86 \pm 5.74$ & 0.86 \\
$\mathrm{Fe}$ & $2.83 \pm 0.15^{\mathrm{a}}$ & $2.69 \pm 0.16^{\mathrm{ab}}$ & $2.51 \pm 0.24^{\mathrm{ab}}$ & $2.27 \pm 0.13^{\mathrm{b}}$ & 0.04 \\
$\mathrm{Cu}$ & $0.77 \pm 0.07$ & $0.84 \pm 0.07$ & $0.66 \pm 0.11$ & $0.76 \pm 0.06$ & 0.65 \\
\hline
\end{tabular}

$\overline{\mathrm{a}, \mathrm{b}}$ Least squares means within a row with different superscripts differ $(P<0.05)$.

${ }^{1}$ Total yield is presented in $\mathrm{g}(\mathrm{Ca}, \mathrm{Mg}, \mathrm{P}, \mathrm{Na}, \mathrm{K})$ or $\mathrm{mg}(\mathrm{Zn}, \mathrm{Fe}, \mathrm{Cu})$.

${ }^{2}$ Models also included the effects of serum mineral concentration (linear, quadratic, or cubic as appropriate), and yield at first postpartum milking (linear, quadratic, or cubic as appropriate).

No association was observed between parity and total yields of $\mathrm{Mg}(P=0.45), \mathrm{Na}(P=0.85), \mathrm{Zn}(P=0.86)$, and $\mathrm{Cu}(P=0.65)$.

Yield. The associations between first-milking colostrum mineral concentrations and yield are presented in Figure 1. Significant linear $(\mathrm{P}: P<0.001 ; \mathrm{Mg}: P=$ 0.04; Fe: $P=0.05$; K: $P<0.001$; Na: $P=0.007$; Zn: $P$ $=0.002)$, quadratic $(\mathrm{P}: P<0.001 ; \mathrm{Mg}: P=0.04 ; \mathrm{Cu}:$ $P=0.03 ; \mathrm{K}: P<0.001 ; \mathrm{Zn}: P=0.01)$, and cubic $(\mathrm{Mg}$ : $P=0.05 ; \mathrm{Cu}: P=0.03 ; \mathrm{Zn}: P=0.03)$ associations were observed. Only linear associations were observed between first-milking colostrum mineral total yields and yield $(P<0.001$ for all minerals).

\section{DISCUSSION}

Although previous research describes concentrations of some minerals in colostrum, to the best of our knowledge, recent studies have only described them in Holstein cows. Furthermore, only 1 study included cows from multiple herds and had a sample size $>24$ cows (n $=55$; Kehoe et al., 2007). Our study used a convenient
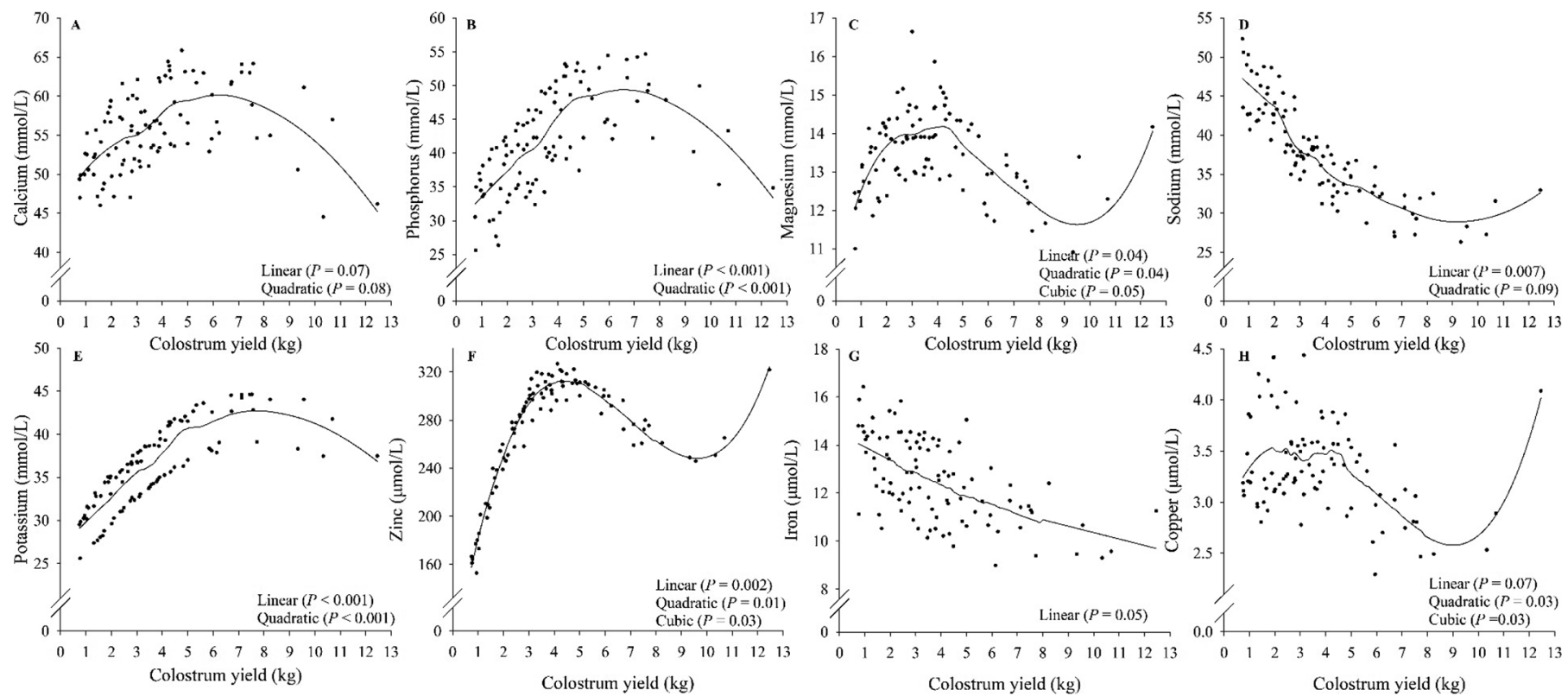

Figure 1. Locally weighted scatterplot smoothing for the association between colostrum harvested at first postpartum milking macro- and trace mineral concentrations and yield as predicted by models that included the effects of cow's serum mineral concentration (linear, quadratic, or cubic), cow's parity, and colostrum yield (linear, quadratic, or cubic). 
sample of 100 multiparous Jersey cows from a single herd fed negative DCAD prepartum diet to describe $\mathrm{Ca}, \mathrm{P}, \mathrm{Mg}, \mathrm{Na}, \mathrm{K}, \mathrm{Zn}, \mathrm{Fe}$, and $\mathrm{Cu}$ concentrations and total yields in first-milking colostrum, compare them to those in second-milking colostrum, and evaluate the associations between these minerals' concentrations and total yields and cow serum mineral concentrations, parity, first-milking colostrum yield, and calving-tofirst milking interval. We caution the readers about the limitation that these specific conditions may impose on the results presented herein. For instance, mineral content in colostrum might vary based on factors such as season (Zarei et al., 2017) and diet (Marques et al., 2011; Wu et al., 2014). Negative compared with positive DCAD did not affect colostrum total $\mathrm{Ca}$ and $\mathrm{Mg}$ concentrations in a study $(\mathrm{DCAD}=-130 \mathrm{mEq} / \mathrm{kg} ; \mathrm{n}$ $=20$ cows/group; Rodney et al., 2018), but increased ionized $(\mathrm{DCAD}=-200 \mathrm{mEq} / \mathrm{kg} ; \mathrm{n}=10$ cows/group; Marques et al., 2011) and total colostrum Ca concentration in others $(\mathrm{DCAD}=-150 \mathrm{mEq} / \mathrm{kg} ; \mathrm{n}=10$ cows/group; Wu et al., 2008). Cows in this study were also fed high concentrations of Ca prepartum (2.9\% of DM). It is unlikely that all Ca provided in the diet was absorbed given the associated efficiency of absorption of its principal source (limestone) and the expected decrease in the overall efficiency of absorption as dietary Ca increases above requirements (NRC, 2001). Given the limited literature available, it is uncertain if the dietary Ca supply in our study influenced colostrum Ca content. Studies in women show that Ca supplementation is not associated with milk Ca content (Prentice et al., 1995), whereas VanHouten et al. (2004) showed that mice fed a low $\mathrm{Ca}$ diet produced milk with lower Ca content. Nevertheless, it is plausible that excessive dietary Ca could interfere with the absorption of other minerals (NRC, 2001). Thus, additional studies presenting a mineral panel including minerals unexplored herein (i.e., Se, Mn, Cl, I), including Jersey cows fed different close-up diets, and from multiple herds are needed to strengthen the current evidence and gain further understanding of factors influencing colostrum mineral concentrations and total yields.

At first postpartum milking, $4 \mathrm{~kg}$ of colostrum was harvested, similar to the average of $4.2 \mathrm{~kg}$ reported by Gavin et al. [2018; $\mathrm{n}=2,988$ Jersey cows (38\% primiparous, $62 \%$ multiparous)] and Sutter et al. [2019; $\mathrm{n}=521$ Holstein cows (30\% primiparous, $70 \%$ multiparous)]. Management at the study dairy resulted in first postpartum milking occurring on average at $>6 \mathrm{~h}$ postpartum, as reported in the survey by Kehoe et al. (2007) for $22 \%$ of the interviewed herds. We recognize that the delay in colostrum harvesting is not optimal for the obtention of high immunoglobulin colostrum (Moore et al., 2005; Godden, 2008); nevertheless, it is unknown how it affects mineral concentrations and total yields. For instance, time from calving to first milking was offered as an explanatory variable for mineral concentrations and total yields in first-milking colostrum and found not significant in all cases in our study. Mineral concentrations observed in our study were similar to those observed in multiparous Holstein cows by Tsioulpas et al. (2007; $\mathrm{n}=8$; in $\mathrm{mmol} / \mathrm{L}$ : 54.2 $\mathrm{Ca}, 52.8 \mathrm{P}, 32.5 \mathrm{Na}, 40.6 \mathrm{~K}$, and $12.1 \mathrm{Mg}$ ) and by Kume and Tanabe $(1993 ; \mathrm{n}=21$; in $\mathrm{mmol} / \mathrm{L} 52.15 \mathrm{Ca}, 56.50$ $\mathrm{P}, 30.01 \mathrm{Na}, 37.85 \mathrm{~K}$, and $12.75 \mathrm{Mg}$; in $\mu \mathrm{mol} / \mathrm{L}: 263.08$ $\mathrm{Zn}, 35.81 \mathrm{Fe}$, and $1.89 \mathrm{Cu}$ ). However, other studies have reported overall higher concentrations of these minerals also in multiparous Holstein cows [Kume et al. (1998), $\mathrm{n}=14$; Aydogdu and Guzelbektes (2018), n = 24; Abd El -Fattah et al. (2012), $\mathrm{n}=12$ cows, sampled over 3 consecutive calvings]. Higher mineral concentrations were reported from freeze-dried colostrum samples compared with those reported in studies using liquid samples (Kehoe et al., 2007; $\mathrm{n}=55$ ). This evident variation in the described mineral concentrations in first-milking colostrum across published studies may be explained by differences in study design (sample size, breed, parity, calving-to-milking interval, prepartum diet, or analytical methods). Unfortunately, many of these details are not provided in the cited studies, and none of them specifically reported total mineral yields, which limited our ability to compare across studies.

Colostrum has the main function of meeting the nutritional requirements of the neonate, and thus it most likely is an important source of minerals for newborn calves. In cow milk, minerals are present as ions in solution or in association with other milk components such as caseins (Fox et al., 2009). Within the evaluated minerals, Ca was the most abundant; $\mathrm{Ca}$ is needed among others for the calcification of bones and teeth in the growing neonate and for the formation of casein micelles in colostrum and milk (Neville, 2005). The high total yields of $\mathrm{Ca}$ in the early postpartum milkings illustrated the large $\mathrm{Ca}$ demands faced by peripartum cows, possibly associated with the commonly observed hypocalcemia around parturition as shown by studies aiming to minimize postpartum Ca outputs through restricted milking (Valldecabres et al., 2021) or lactogenic signal inhibition (Vanacker et al., 2017). Additional minerals evaluated in the present study hold important roles for the neonate and as part of the mammary gland secretion. Briefly, $\mathrm{P}$ is needed for casein micelle and phospholipids formation and is necessary along with $\mathrm{Mg}$ for calf bone mineral formation; $\mathrm{Na}$ and $\mathrm{K}$ are key ions involved in osmotic pressure and acid-base regulation; and $\mathrm{Zn}, \mathrm{Fe}$, and $\mathrm{Cu}$ have key roles as antioxidants, enzyme cofactors, and immune cell activity (Fox et al., 2009; Goff, 2018). 
A modest yield increase from first to second postpartum milking was observed, in agreement with observations in Jersey and Jersey $\times$ Holstein crossbreed cows in another study from our group $(5.8 \pm 1.0$ and $7.0 \pm$ $0.7 \mathrm{~kg} ; \mathrm{LSM} \pm$ SE; Valldecabres et al., 2021) and observations from 10 Holstein cows (5.3 and 6.7 L; SalgadoHernández et al., 2014a). Compared with first-milking colostrum, we observed a decrease in $\mathrm{Ca}, \mathrm{Mg}, \mathrm{Na}, \mathrm{Cu}$, $\mathrm{Fe}$, and $\mathrm{Zn}$ concentrations and $\mathrm{Mg}, \mathrm{Zn}, \mathrm{Fe}$, and $\mathrm{Cu}$ total yields in second-milking colostrum. In agreement with our findings, Kume and Tanabe (1993) reported a decrease from 0 to $12 \mathrm{~h}$ postpartum of $\mathrm{Ca}(19.8 \%)$, $\mathrm{Mg}(32.2 \%), \mathrm{Zn}(40.7 \%), \mathrm{Cu}(25.0 \%)$, and $\mathrm{Fe}(25.0 \%)$, and a similar K concentration. Tsioulpas et al. (2007) reported a decrease from d 1 to 2 postpartum of Ca (26.9\%) and $\mathrm{Mg}(31.4 \%)$. However, these 2 studies also reported a decrease in $\mathrm{P}$ concentration [Kume and Tanabe, 1993 (18.3\%); Tsioulpas et al., 2007 (22.9\%)], and Tsioulpas et al. (2007) also reported a $10.8 \%$ decrease in $\mathrm{K}$ concentration from d 1 to 2 postpartum, which was not observed in our study. Tsioulpas et al. (2007) do not specify the postpartum milking number for samples obtained at d 1 and 2; thus, it is plausible that data from their study does not directly compare with our first- and second-milking colostrum. The decrease in mineral concentrations agrees with observations for other colostrum components (Foley and Otterby, 1978; Silva-del-Río et al., 2017). For those minerals associated with casein micelles ( $\mathrm{Ca}$ and $\mathrm{P}$ ), its content is roughly proportional to milk casein concentration (Neville, 2005; Jensen et al., 2012); therefore, its decrease from first to second postpartum milking may be associated with a decrease in casein concentration and micelle diameter from d 1 to 2 postpartum, although colostrum casein micelles are usually less mineralized than milk casein micelles (Foley and Otterby, 1978; Tsioulpas et al., 2007; McGrath et al., 2016). Furthermore, lactose, the main osmotic component in milk increases from $\mathrm{d}$ 1 to 2 postpartum (2.7 to 3.0\%; Tsioulpas et al., 2007), increasing the water content and decreasing the overall concentrations of other components (Fox et al., 2009; Costa et al., 2019). Unpublished data from our group suggest that mineral concentrations stabilize after the second postpartum milking, in agreement with Foley and Otterby (1978). For 20 multiparous Jersey and Jersey $\times$ Holstein crossbreed cows, second versus third postpartum milking was as follows: $\mathrm{Ca}(P=0.49), \mathrm{P}(P$ $=0.61), \mathrm{Mg}(P=0.02), \mathrm{Na}(P=1.00), \mathrm{K}(P=0.99)$, Zn $(P=0.26)$, Fe $(P=0.75)$, and $\mathrm{Cu}(P=0.78)$; and third vs. fourth postpartum milking: Ca $(P=1.00)$, $\mathrm{P}(P=0.86), \mathrm{Mg}(P=0.59), \mathrm{Na}(P=0.99), \mathrm{K}(P=$ $0.98), \mathrm{Zn}(P=0.96), \mathrm{Fe}(P=0.78)$, and $\mathrm{Cu}(P=0.93$; unpublished data).
Despite that all cows were under the same management conditions and sampled during a short period of time in our study, we observed an important variability in colostrum mineral concentrations and total yields across cows, as evidenced with the presented standard deviation, $95 \%$ confidence intervals, and the generally high coefficients of variations (Ca: $24 \%, \mathrm{P}: 31 \%, \mathrm{Mg}$ : $23 \%$, Na: 35\%, K: 21\%, Zn: 42\%, Fe: 30\%, Cu: $37 \%$ ). We evaluated cow serum mineral concentrations, parity, first-milking colostrum yield, and calving-to-first milking interval as explanatory variables for the observed first-milking colostrum mineral concentrations and total yields. Time from calving to milking was not an explanatory variable for first-milking colostrum mineral concentrations and total yields in our study; its potential collinearity with first-milking colostrum yield, as well as the nature of the present data set, may have prevented us from detecting the association. Nevertheless, it is also plausible that dynamics for colostrum mineral concentrations are different than those for other colostrum components.

Plasma minerals reach the alveoli lumen through different paracellular and transcellular pathways (Montalbetti et al., 2014). Thus, it would have not been surprising if cow serum mineral concentrations were associated with colostrum mineral concentrations. However, although plasma concentrations of other nutrients (acetate, nonesterified fatty acids, BHB, and triglycerides) have been reported as major determinants of their uptake by the mammary glands (Miller et al., 1991), we only observed a significant association between serum and first-milking colostrum $\mathrm{Cu}$ concentrations. In partial agreement, no associations between first-milking colostrum mineral concentrations and serum were observed in studies evaluating Ca (Salgado-Hernández et al., 2014b; $\mathrm{n}=16$ multiparous Holstein cows) or $\mathrm{Cu}$, Se, Mn, and Zn (Pavlata et al., 2004; n = 12 Holstein cows). Studies using milk samples reported no significant correlations for milk and serum $\mathrm{P}, \mathrm{Mg}, \mathrm{Cu}, \mathrm{Fe}$, and Zn concentrations, a negative correlation for milk and serum $\mathrm{Na}$ concentration, and positive correlations for milk and serum $\mathrm{K}$ and $\mathrm{Ca}$ concentrations [Pechová et al., 2008 ( $\mathrm{n}=35$ Holstein cows at 7 to 188 DIM); Denholm et al., 2019 ( $\mathrm{n}=479$ Holstein-Friesian cows sampled once or twice at unspecified lactation stage)]. Research in lactating women shows that $\mathrm{Fe}, \mathrm{Cu}$, and Zn concentrations from breast milk samples collected within 3 mo or at 9 mo postpartum are independent of plasma concentrations (Domellöf et al., 2004; Hannan et al., 2009). Thus, further research is needed to elucidate if the observed association between colostrum and serum $\mathrm{Cu}$ concentration is a coincidental finding from this study or if it represents a biological association. 
Serum concentrations are not the best indicators of a dam's mineral status for all minerals evaluated herein; therefore, if the evaluation of the associations between cow mineral status and colostrum mineral concentrations and total yields were pursued, the nature of the samples collected should be further considered (Goff, 2018).

The parity effect on colostrum mineral concentrations has been evaluated in previous studies with multiparous Holstein cows. In partial agreement with our findings, Kume and Tanabe (1993) reported higher concentration of $\mathrm{Ca}$ for second-parity cows $(\mathrm{n}=13)$ compared with third $(\mathrm{n}=18)$ and fourth $(\mathrm{n}=8)$ parity cows, and a higher concentration of $\mathrm{P}$ compared with third-or-greater parity cows, along with no differences in $\mathrm{Mg}, \mathrm{Cu}$, and $\mathrm{Fe}$, and a lower $\mathrm{Zn}$ concentration for third compared with fifth-or-greater parity cows $(\mathrm{n}=$ 6). Kume et al. (1998) observed higher colostrum Mg and $\mathrm{P}$ concentrations for second $(\mathrm{n}=6)$ compared with third-or-greater parity cows $(\mathrm{n}=8)$, along with similar concentrations of $\mathrm{Ca}, \mathrm{K}, \mathrm{Na}, \mathrm{Fe}$, and $\mathrm{Zn}$. Additional studies suggest that mineral concentrations are higher for primiparous than multiparous Holstein cows (Salgado-Hernández et al., 2014b; Aydogdu and Guzelbektes, 2018). Differences in study design (no primiparous cows included in our study), data analysis (adjustment by the effect of yield in our statistical models), or breed (Jersey vs. Holstein) may explain the differences observed between our results and those reported by Kume and collaborators. However, it is interesting to note the agreement on no association between parity and colostrum Zn concentration among the 3 studies evaluating it [ours, Kume and Tanabe (1993), and Kume et al. (1998)].

We observed significant linear and higher degree polynomial associations between first-milking colostrum mineral concentrations and yield for all the evaluated minerals except for $\mathrm{Ca}$, whereas only linear associations were observed between first-milking colostrum total mineral yields and yield for all the evaluated minerals. In the present study, $<5.0 \mathrm{~kg}$ of first-milking colostrum was harvested from $75 \%$ of the cows, whereas 5.0 to $12.5 \mathrm{~kg}$ were harvested from $25 \%$ of the cows. First-milking colostrum mineral concentrations in these higher-yielding cows likely influenced the observed associations represented in Figure 1. In an attempt to better understand this association, we used the previously built models to assess the effect of yield on first-milking colostrum mineral concentrations in the subgroup of cows whose yield was within the interquartile range $(1.99-4.86 \mathrm{~kg} ; \mathrm{n}=50)$. In this subset of cows, significant positive linear associations were observed between yield and $\mathrm{P}$ and $\mathrm{K}$ concentrations at first postpartum milking; $1 \mathrm{~kg}$ increase in yield was associated with 5.63 and $2.85 \mathrm{mmol} / \mathrm{L}$ higher $\mathrm{P}(P$ $=0.03)$ and $\mathrm{K}(P=0.01)$ concentrations, respectively. However, no significant associations were observed for $\mathrm{Ca}, \mathrm{Mg}, \mathrm{Na}, \mathrm{Zn}, \mathrm{Fe}$, and $\mathrm{Cu}$. Thus, we caution the readers when interpreting the results given the heterogeneity of the reported observations. Because standards of quality for colostrum mineral concentrations are not established, we did not try to identify a critical level of production. Although a negative association between colostrum yield and concentration of other components has been commonly reported (Morin et al., 2010; Silvadel-Río et al., 2017), that type of association does not seem to generally describe the association between mineral concentrations and yield at first postpartum milking and warrants further investigation. If colostrum mineral supply is key for calf health, further research is warranted to ensure an optimum use of this supply given the variability observed in this study.

\section{CONCLUSIONS}

Under the conditions of the present study (multiparous Jersey cows fed a negative DCAD prepartum diet under same management conditions), Ca was the most abundant mineral in first-milking colostrum, followed in order of decreasing concentration by $\mathrm{P}, \mathrm{Na}, \mathrm{K}, \mathrm{Mg}$, $\mathrm{Zn}, \mathrm{Fe}$, and $\mathrm{Cu}$. However, colostrum mineral concentrations and total yields highly varied between cows. Serum and first-milking colostrum $\mathrm{Cu}$ concentrations were positively associated, but no significant associations were observed with other mineral concentrations or total yields. Parity was associated with first-milking colostrum Ca, P, K, and Fe concentrations and total yields, with younger cows having higher concentrations and total yields of these minerals. First-milking colostrum yield was associated with colostrum $\mathrm{P}, \mathrm{Mg}, \mathrm{Na}$, $\mathrm{K}, \mathrm{Zn}, \mathrm{Fe}$, and $\mathrm{Cu}$ concentrations and total yields of all the evaluated minerals. From first- to second-milking colostrum, $\mathrm{Ca}, \mathrm{Mg}, \mathrm{Na}, \mathrm{Cu}, \mathrm{Fe}$, and $\mathrm{Zn}$ concentrations, and $\mathrm{Mg}, \mathrm{Zn}, \mathrm{Fe}$, and $\mathrm{Cu}$ total yields decreased. To the best of our knowledge, this is the first study describing colostrum mineral concentrations and total yields in Jersey cows.

\section{ACKNOWLEDGMENTS}

The authors appreciate the collaboration of the study herd for allowing us to use their facilities, cows, and records. We gratefully acknowledge Diego Rolle and Sonia Rodríguez (Veterinary Medicine Teaching and Research Center, Tulare, CA) for their work on sample and data collection, Sabine A. Hargrave (California Animal Health and Food Safety Laboratory, University of California, Davis, CA), and Jesse P. Goff (Iowa 
State University, Ames, IA) and Ernesto Simó-Alfonso (University of Valencia, Valencia, Spain) for their assistance on manuscript preparation. The authors have not stated any conflicts of interest.

\section{REFERENCES}

Abd El-Fattah, A. M., F. H. R. Abd Rabo, S. M. EL-Dieb, and H. A. El-Kashef. 2012. Changes in composition of colostrum of Egyptian buffaloes and Holstein cows. BMC Vet. Res. 8:19. https://doi.org/ 10.1186/1746-6148-8-19.

Auldist, M. J., K. A. Johnston, N. J. White, W. P. Fitzsimons, and M. J. Boland. 2004. A comparison of the composition, coagulation characteristics and cheesemaking capacity of milk from Friesian and Jersey dairy cows. J. Dairy Res. 71:51-57. https://doi.org/10 $.1017 /$ S0022029903006575.

Aydogdu, U., and H. Guzelbektes. 2018. Effect of colostrum composition on passive calf immunity in primiparous and multiparous dairy cows. Vet. Med. (Praha) 63:1-11. https://doi.org/10.17221/ 40/2017-VETMED.

Bates, A., M. Wells, R. A. Laven, and M. Simpson. 2019. Reduction in morbidity and mortality of dairy calves from an injectable trace mineral supplement. Vet. Rec. 184:680. https://doi.org/10.1136/ vr.105082.

Carroll, S. M., E. J. DePeters, S. J. Taylor, M. Rosenberg, H. PerezMonti, and V. A. Capps. 2006. Milk composition of Holstein, Jersey, and Brown Swiss cows in response to increasing levels of dietary fat. Anim. Feed Sci. Technol. 131:451-473. https://doi.org/ 10.1016/j.anifeedsci.2006.06.019.

Cerbulis, J., and H. M. Farrell Jr.. 1976. Composition of the milks of dairy cattle. II. Ash, calcium, magnesium, and phosphorus. J. Dairy Sci. 59:589-593. https://doi.org/10.3168/jds.S0022 -0302(76)84245-2.

Costa, A., N. Lopez-Villalobos, N. W. Sneddon, L. Shalloo, M. Franzoi, M. De Marchi, and M. Penasa. 2019. Invited review: Milk lactose - Current status and future challenges in dairy cattle. J. Dairy Sci. 102:5883-5898. https://doi.org/10.3168/jds.2018-15955.

Denholm, S. J., A. A. Sneddon, T. N. McNeilly, S. Bashir, M. C. Mitchell, and E. Wall. 2019. Phenotypic and genetic analysis of milk and serum element concentrations in dairy cows. J. Dairy Sci. 102:11180-11192. https://doi.org/10.3168/jds.2019-16960.

Domellöf, M., B. Lönnerdal, K. G. Dewey, R. J. Cohen, and O. Hernell. 2004. Iron, zinc, and copper concentrations in breast milk are independent of maternal mineral status. Am. J. Clin. Nutr. 79:111-115. https://doi.org/10.1093/ajen/79.1.111.

Dunn, A., A. Ashfield, B. Earley, M. Welsh, A. Gordon, M. McGee, and S. J. Morrison. 2017. Effect of concentrate supplementation during the dry period on colostrum quality and effect of colostrum feeding regimen on passive transfer of immunity, calf health, and performance. J. Dairy Sci. 100:357-370. https://doi.org/10.3168/ jds.2016-11334.

Ferguson, J. D., D. T. Galligan, and N. Thomsen. 1994. Principal descriptors of body condition score in Holstein cows. J. Dairy Sci. 77:2695-2703. https://doi.org/10.3168/jds.S0022-0302(94)77212 $-\mathrm{X}$.

Foley, J. A., and D. E. Otterby. 1978. Availability, storage, treatment, composition, and feeding value of surplus colostrum: A Review. J. Dairy Sci. 61:1033-1060. https://doi.org/10.3168/jds.S0022 -0302(78)83686-8.

Fox, P. F., T. Uniacke-Lowe, P. L. H. McSweeney, and J. A. O'Mahony. 2009. Dairy Chemistry and Biochemistry. 2nd ed. Springer.

Gavin, K., H. Neibergs, A. Hoffman, J. N. Kiser, M. A. Cornmesser, S. A. Haredasht, B. Martínez-López, J. R. Wenz, and D. A. Moore. 2018. Low colostrum yield in Jersey cattle and potential risk factors. J. Dairy Sci. 101:6388-6398. https://doi.org/10.3168/ jds. $2017-14308$.

Godden, S. 2008. Colostrum management for dairy calves. Vet. Clin. North Am. Food Anim. Pract. 24:19-39. https://doi.org/10.1016/ j.cvfa.2007.10.005.
Goff, J. P. 2018. Invited review: Mineral absorption mechanisms, mineral interactions that affect acid-base and antioxidant status, and diet considerations to improve mineral status. J. Dairy Sci. 101:2763-2813. https://doi.org/10.3168/jds.2017-13112.

Goff, J. P., K. Kimura, and R. L. Horst. 2002. Effect of mastectomy on milk fever, energy, and vitamins $\mathrm{A}, \mathrm{E}$, and $\beta$-carotene status at parturition. J. Dairy Sci. 85:1427-1436. https://doi.org/10.3168/ jds.S0022-0302(02)74210-0.

Hannan, M. A., B. Faraji, J. Tanguma, N. Longoria, and R. C. Rodriguez. 2009. Maternal milk concentration of zinc, iron, selenium, and iodine and its relationship to dietary intakes. Biol. Trace Elem. Res. 127:6-15. https://doi.org/10.1007/s12011-008-8221-9.

Jensen, H. B., N. A. Poulsen, K. K. Andersen, M. Hammershøj, H. D. Poulsen, and L. B. Larsen. 2012. Distinct composition of bovine milk from Jersey and Holstein-Friesian cows with good, poor, or noncoagulation properties as reflected in protein genetic variants and isoforms. J. Dairy Sci. 95:6905-6917. https://doi.org/10.3168/ jds.2012-5675.

Kehoe, S. I., A. J. Heinrichs, M. L. Moody, C. M. Jones, and M. R. Long. 2011. Comparison of immunoglobulin G concentrations in primiparous and multiparous bovine colostrum1. Prof. Anim. Sci. 27:176-180. https://doi.org/10.15232/S1080-7446(15)30471-X.

Kehoe, S. I., B. M. Jayarao, and A. J. Heinrichs. 2007. A survey of bovine colostrum composition and colostrum management practices on Pennsylvania dairy farms. J. Dairy Sci. 90:4108-4116. https:// doi.org/10.3168/jds.2007-0040.

Kertz, A. F., T. M. Hill, J. D. Quigley III, A. J. Heinrichs, J. G. Linn, and J. K. Drackley. 2017. A 100-Year Review: Calf nutrition and management. J. Dairy Sci. 100:10151-10172. https://doi.org/10 $.3168 /$ jds.2017-13062.

Kume, S., E. Yanamoto, T. Kudo, T. Toharmat, and I. Nonaka. 1998. Effect of parity on mineral concentration in milk and plasma of Holstein cows during early lactation. Asian-Australas. J. Anim. Sci. 11:133-138. https://doi.org/10.5713/ajas.1998.133.

Kume, S., and S. Tanabe. 1993. Effect of parity on colostral mineral concentrations of Holstein cows and value of colostrum as a mineral source for newborn calves. J. Dairy Sci. 76:1654-1660. https:/ /doi.org/10.3168/jds.S0022-0302(93)77499-8.

Mann, S., F. A. Leal Yepes, T. R. Overton, A. L. Lock, S. V. Lamb, J. J. Wakshlag, and D. V. Nydam. 2016. Effect of dry period dietary energy level in dairy cattle on volume, concentrations of immunoglobulin G, insulin, and fatty acid composition of colostrum. J. Dairy Sci. 99:1515-1526. https://doi.org/10.3168/jds.2015-9926.

Marques, L. T., V. Fischer, M. B. Zanela, M. E. R. Ribeiro, W. Stumpf Junior, and C. M. Rodrigues. 2011. Produção leiteira, composição do leite e perfil bioquímico sanguíneo de vacas lactantes sob suplementação com sal aniônico. Rev. Bras. Zootec. 40:1088-1094. https://doi.org/10.1590/S1516-35982011000500021.

Maunsell, F. P., D. E. Morin, P. D. Constable, W. L. Hurley, G. C McCoy, I. Kakoma, and R. E. Isaacson. 1998. Effects of mastitis on the volume and composition of colostrum produced by Holstein cows. J. Dairy Sci. 81:1291-1299. https://doi.org/10.3168/ jds.S0022-0302(98)75691-7.

McGrath, B. A., P. F. Fox, P. L. H. McSweeney, and A. L. Kelly. 2016. Composition and properties of bovine colostrum: A review. Dairy Sci. Technol. 96:133-158. https://doi.org/10.1007/s13594 $-015-0258-x$

Melton, L. A., M. L. Tracy, and G. Möller. 1990. Screening trace elements and electrolytes in serum by inductively-coupled plasma emission spectrometry. Clin. Chem. 36:247-250. https://doi.org/ 10.1093/clinchem/36.2.247.

Miller, P. S., B. L. Reis, C. C. Calvert, E. J. DePeters, and R. L. Baldwin. 1991. Patterns of nutrient uptake by the mammary glands of lactating dairy cows. J. Dairy Sci. 74:3791-3799. https://doi.org/ 10.3168/jds.S0022-0302(91)78571-8.

Montalbetti, N., M. G. Dalghi, C. Albrecht, and M. A. Hediger. 2014. Nutrient transport in the mammary gland: Calcium, trace minerals and water soluble vitamins. J. Mammary Gland Biol. Neoplasia 19:73-90. https://doi.org/10.1007/s10911-014-9317-9.

Moore, M., J. W. Tyler, M. Chigerwe, M. E. Dawes, and J. R. Middleton. 2005. Effect of delayed colostrum collection on colostral IgG 
concentration in dairy cows. J. Am. Vet. Med. Assoc. 226:13751377. https://doi.org/10.2460/javma.2005.226.1375.

Morin, D. E., S. V. Nelson, D. Reid, D. W. Nagy, G. E. Dahl, and P. D. Constable. 2010. Effect of colostral volume, interval between calving and first milking, and photoperiod on colostral IgG concentrations in dairy cows. J. Am. Vet. Med. Assoc. 237:420-428. https://doi.org/10.2460/javma.237.4.420.

Morrill, K. M., E. Conrad, A. Lago, J. Campbell, J. Quigley, and H. Tyler. 2012. Nationwide evaluation of quality and composition of colostrum on dairy farms in the United States. J. Dairy Sci. 95:3997-4005. https://doi.org/10.3168/jds.2011-5174.

Neville, M. C. 2005. Calcium secretion into milk. J. Mammary Gland Biol. Neoplasia 10:119-128. https://doi.org/10.1007/s10911-005 $-5395-\mathrm{z}$.

NRC. 2001. Nutrient Requirements of Dairy Cattle. 7th ed. Natl. Acad. Sci.

Parrish, D. B., G. H. Wise, J. S. Hughes, and F. W. Atkeson. 1950. Properties of the colostrum of the dairy cow. v. yield, specific gravity and concentrations of total solids and its various components of colostrum and early milk. J. Dairy Sci. 33:457-465. https://doi .org/10.3168/jds.S0022-0302(50)91921-7.

Pavlata, L., A. Pechová, and R. Dvořák. 2004. Microelements in colostrum and blood of cows and their calves during colostral nutrition. Acta Vet. Brno 73:421-429. https://doi.org/10.2754/ avb200473040421.

Pechová, A., L. Pavlata, R. Dvořák, and E. Lokajová. 2008. Contents of $\mathrm{Zn}, \mathrm{Cu}, \mathrm{Mn}$ and $\mathrm{Se}$ in milk in relation to their concentrations in blood, milk yield and stage of lactation in dairy cattle. Acta Vet. Brno 77:523-531. https://doi.org/10.2754/avb200877040523.

Playford, R. J., and M. J. Weiser. 2021. Bovine colostrum: Its constituents and uses. Nutrients 13:265. https://doi.org/10.3390/ nu13010265.

Prentice, A., L. M. A. Jarjou, T. J. Cole, D. M. Stirling, B. Dibba, and S. Fairweather-Tait. 1995. Calcium requirements of lactating Gambian mothers: Effects of a calcium supplement on breast-milk calcium concentration, maternal bone mineral content, and urinary calcium excretion. Am. J. Clin. Nutr. 62:58-67. https://doi .org/10.1093/ajcn/62.1.58

Rodney, R. M., N. Martinez, E. Block, L. L. Hernandez, P. Celi, C. D. Nelson, J. E. P. Santos, and I. J. Lean. 2018. Effects of prepartum dietary cation-anion difference and source of vitamin D in dairy cows: Vitamin D, mineral, and bone metabolism. J. Dairy Sci. 101:2519-2543. https://doi.org/10.3168/jds.2017-13737.

Salgado-Hernández, E. G., A. Aparicio-Cecilio, F. H. Velásquez-Forero, D. A. Castillo-Mata, and J. Bouda. 2014a. Effect of the first and second postpartum partial milking on blood serum calcium concentration in dairy cows. Czech J. Anim. Sci. 59:128-133. https://doi.org/10.17221/7292-CJAS.

Salgado-Hernández, E. G., J. Bouda, A. Villa-Godoy, J. L. RomanoMuñoz, A. J. Gutiérrez-Chávez, and F. Velásquez-Forero. 2014b. Metabolites of vitamin D and minerals in blood and colostrum of primiparous and multiparous dairy cows postpartum. Czech J. Anim. Sci. 59:11-18. https://doi.org/10.17221/7189-CJAS.

Silva-del-Río, N., D. Rolle, A. García-Muñoz, S. Rodríguez-Jiménez, A. Valldecabres, A. Lago, and P. Pandey. 2017. Colostrum immunoglobulin G concentration of multiparous Jersey cows at first and second milking is associated with parity, colostrum yield, and time of first milking, and can be estimated with Brix refractometry. J. Dairy Sci. 100:5774-5781. https://doi.org/10.3168/jds.2016-12394.
Sprecher, D. J., D. E. Hostetler, and J. B. Kaneene. 1997. A lameness scoring system that uses posture and gait to predict dairy cattle reproductive performance. Theriogenology 47:1179-1187. https:// doi.org/10.1016/S0093-691X(97)00098-8.

Sutter, F., S. Borchardt, G. M. Schuenemann, E. Rauch, M. Erhard, and W. Heuwieser. 2019. Evaluation of 2 different treatment procedures after calving to improve harvesting of high-quantity and high-quality colostrum. J. Dairy Sci. 102:9370-9381. https://doi .org/10.3168/jds.2019-16524.

Teixeira, A. G. V., F. S. Lima, M. L. S. Bicalho, A. Kussler, S. F. Lima, M. J. Felippe, and R. C. Bicalho. 2014. Effect of an injectable trace mineral supplement containing selenium, copper, zinc, and manganese on immunity, health, and growth of dairy calves. J. Dairy Sci. 97:4216-4226. https://doi.org/10.3168/jds.2013-7625.

Tsioulpas, A., A. S. Grandison, and M. J. Lewis. 2007. Changes in physical properties of bovine milk from the colostrum period to early lactation. J. Dairy Sci. 90:5012-5017. https://doi.org/10 $.3168 /$ jds.2007-0192.

Valldecabres, A., R. B. Lopes, A. Lago, C. Blanc, and N. Silva-del-Río. 2021. Effects of postpartum milking strategy on plasma mineral concentrations and colostrum, transition milk, and milk yield and composition in multiparous dairy cows. J. Dairy Sci. https://doi .org/10.3168/jds.2021-20590.

Valldecabres, A., J. A. A. Pires, and N. Silva-del-Río. 2018. Effect of prophylactic oral calcium supplementation on postpartum mineral status and markers of energy balance of multiparous Jersey cows. J. Dairy Sci. 101:4460-4472. https://doi.org/10.3168/jds.2017 $-12917$.

Vanacker, N., S. Ollier, F. Beaudoin, R. Blouin, and P. Lacasse. 2017. Effect of inhibiting the lactogenic signal at calving on milk production and metabolic and immune perturbations in dairy cows. J. Dairy Sci. 100:5782-5791. https://doi.org/10.3168/jds.2017-12570.

VanHouten, J., P. Dann, G. McGeoch, E. M. Brown, K. Krapcho, M. Neville, and J. J. Wysolmerski. 2004. The calcium-sensing receptor regulates mammary gland parathyroid hormone-related protein production and calcium transport. J. Clin. Invest. 113:598-608. https://doi.org/10.1172/JCI200418776.

Wu, W. X., J. X. Liu, G. Z. Xu, and J. A. Ye. 2008. Calcium homeostasis, acid-base balance, and health status in periparturient Holstein cows fed diets with low cation-anion difference. Livest. Sci. 117:7-14. https://doi.org/10.1016/j.livsci.2007.11.005.

Wu, Z., J. K. Bernard, K. P. Zanzalari, and J. D. Chapman. 2014. Effect of feeding a negative dietary cation-anion difference diet for an extended time prepartum on postpartum serum and urine metabolites and performance. J. Dairy Sci. 97:7133-7143. https:// doi.org/10.3168/jds.2014-8273.

Zarei, S., G. Reza Ghorbani, M. Khorvash, O. Martin, A. Hossein Mahdavi, and A. Riasi. 2017. The Impact of Season, Parity, and Volume of Colostrum on Holstein Dairy Cows Colostrum Composition. Agric. Sci. 8:572-581. https://doi.org/10.4236/as.2017 .87043 .

\section{ORCIDS}

A. Valldecabres () https://orcid.org/0000-0002-3235-2487

N. Silva-del-Río @ https://orcid.org/0000-0002-2826-6797 